\title{
Halide Edib Adivar (1982-1964) as a National Symbol of the Republic of Turkey
}

\section{A. Savin ${ }^{1}$}

${ }^{1}$ P. G. Demidov Yaroslavl State University, 14 Sovetskaya str., Yaroslavl 150003, Russian Federation

DOI: $10.18255 / 1996-5648-2021-2-164-169$

Research article Full text in Russian

The article is dedicated to Halide Edip - outstanding novelist, scientist, public figure. The events of her personal life and political processes that took place in the last years of the Ottoman Empire and in the Republican period are reflected in her articles, memoirs, novels and scientific works. She raised topical issues such as the social status of Turkish women, their education and participation in political life, aspects of nationalist ideas, the correlation of tradi-tions and innovations in public life and the role of religion.

Keywords: Halide Edip; biography; Turket; memoirs; women`s rights

INFORMATION ABOUT AUTHORS

\begin{tabular}{l|l} 
Savin, Dmitry A. & $\begin{array}{l}\text { E-mail: savind@yandex.ru } \\
\text { Cand. Sc. (History) }\end{array}$
\end{tabular} 


\title{
Халиде Эдип Адывар (1882-1964) \\ как национальный символ \\ Турецкой Республики
}

\author{
Д. А. Савин ${ }^{1}$
}

19рославский государственный университет им. П. Г. Демидова, ул. Советская, 14, Ярославль, 150003, Российская Федерация

DOI: 10.18255/1996-5648-2021-2-164-169

УДК $94(560)+929$

Научная статья

Полный текст на русском языке

Статья посвящена Халиде Эдип, писательнице и общественному деятелю. События ее личной жизни и политические процессы, проходившие в последние годы существования Османской империи и в республиканской Турции, нашли отражение в ее статьях, мемуарах, романах и научных трудах. Она поднимала актуальные проблемы, такие как социальный статус турецких женщин, образование и воспитание, участие женщин в политической жизни, соотношение традиций и инноваций в общественной жизни, роль религии.

ключевые слова: Халиде Эдип; биография; Турция; мемуары; права женщин ИНФОРМАЦИЯ ОБ АВТОРАХ

Савин, Дмитрий Александрович $\mid$ E-mail: savind@yandex.ru

Кандидат исторических наук

Личность Халиде Эдип в российском научном пространстве изучена слабо. Большинство исследований, посвященных биографии писательницы, написаны на турецком и английском языках и не переводились на русский язык. Первая биография Халиде Эдип на русском языке была опубликована только в 2018 г. [1], хотя ее творческое наследие давно уже интересует филологов и историков.

Литературное наследие X. Эдип почти не переводилось на русский язык. Отечественный тюрколог А. Т. Сибгатуллина в своей работе отмечает, что «в советский период были осуществлены всего три перевода произведений Халиде Эдип на русский язык, которые сейчас практически недоступны читателю» [1, с. 170]. Требуют изучения биография писательницы, ее роль как общественного деятеля, борца за права женщин, участие в освободительном движении, взгляды на педагогику и политику.

(с) Савин Д. А., 2021

Статья открытого доступа под лицензией СС BY (https://creativecommons.org/licenses/by/4.0/) 
При знакомстве с биографией Халиде Эдип становится очевидным, что это многогранная личность, оставившая след в истории Османской империи и Турецкой Республики. Она была первой мусульманской выпускницей Американского колледжа для девочек в Стамбуле, первой турецкой писательницей, опубликовавшей в 1935 г. роман на английском языке («Клоун и его дочь»), первой женщиной-капралом в национальной армии, первой женщиной-профессором в Стамбульском университете [2, с. 217]. Именно она была одной из основательниц женского движения в Турции, стояла у истоков создания первого новостного агентства страны («Анатолия»), принимала активное участие в благотворительной деятельности в годы Первой мировой войны и в ходе освободительного движения, работала санитаркой, оказывала помощь раненым. Особенно много внимания она уделяла помощи детям-сиротам: туркам и армянам. Х. Эдип выступала на собраниях, митингах, в прессе.

Возможно, ее жизнь сложилась бы иначе, если бы ее, как многих мусульманских женщин, воспитывали как будущих жен и домохозяек. Однако отец Халиде - Мехмет Эдип-бей, служивший секретарем султана (1876-1909 гг.) Абдул-Хамида II, был весьма дальновидным человеком и стремился дать дочери образование. Он был либералом и сторонником вестернизации - процесса, предполагавшего восприятие и внедрение лучших образцов и достижений европейской мысли. Дом в стамбульском районе Бешикташ, где жила X. Эдип, представлял собой особняк старого типа, окруженный глициниями, что нашло отражение в названии первой части ее мемуаров: «Дом с глицинией», где она описывала детство и юность. В доме она жила с бабушкой Накие-ханум и дедушкой Али-эфенди.

Наличие богатой библиотеки предопределило интерес девочки к чтению. Она знакомилась с мусульманскими обычаями и традициями, основами религиозного воспитания, получала уроки ведения домашнего хозяйства, что не могло впоследствии не отразиться на ее творчестве, на характерах героев ее произведений.

Совсем другой мир окружал ее в доме отца Мехмет-Эдип-бея, заинтересованного в том, чтобы дать дочери воспитание на английский манер. Х. Э. (Эдип) отмечала в своих воспоминаниях, что «...воспитывалась как британская девочка, поскольку отец ее считал, что величие британцев было обусловлено воспитанием. Он же взял на себя инициативу покупать ей платья, нижнее белье, обувь, даже платки...» [3, с. 23]. В 1891 г. отец отдал Халиде в миссионерскую школу для девочек, где вместе с ней обучались представители различных национальностей. Однако султан остался недоволен таким решением Мехмета Эдип-бея, и Халиде вынуждена была прекратить посещение заведения. Преподаватели школы приходили к ней домой с целью проведения занятий по различным предметам. Как отмечает А. Сибгатуллина, «у лучших учителей города она брала уроки по европейской музыке, турецкой литературе, математике, арабскому, персидскому 
и фрранцузскому языкам. Интерес к иностранным языкам привел юную девушку к увлечению художественными переводами» [1, с. 12].

Круг ее чтения был широк и включал романы английской писательницы Дж. Эллиот, роман американского писателя Дж. Эббота «Мать», который она перевела на турецкий язык в 1897 г.; она отлично знала творчество У. Шекспира, а трагедию «Гамлет» могла прочесть наизусть.

Образование отнюдь не способствовало кризису идентичности. Наоборот, оно позволило Х. Эдип интеллектуально развиваться, понимать культуру и менталитет разных народов и стран. Она свободно говорила на английском, активно общалась с турецкими и зарубежными интеллектуалами, знакомыми ее отца. В обществе ее ценили за ум, смелые взгляды и невероятную работоспособность, которая проявлялась с юных лет.

Общественная деятельность Х. Эдип началась с 1908 г., когда она стала публиковать статьи по вопросам образования и статуса турецких женщин в газете «Танин» и журнале «Демет». В 1913 г. Х. Эдип основала Ассоциацию женщин «Teali-i nisvan», целью которой было улучшение их социального статуса. Имя Х. Эдип стало широко известно после катастрофического для Османской империи завершения Первой мировой войны, когда над страной нависла угроза не только территориального раздела, но и потери суверенитета. Слабое султанское правительство не имело средств для противостояния захватническим планам европейских держав и фрактически предало государство и народ, разрешив войскам Англии, Греции и Италии высадиться на территории Малой Азии.

В сложных для страны условиях Х. Эдип не побоялась выступить с пламенной речью на митинге 6 июня 1919 г. (во время оккупации Измира греческими войсками) в Стамбуле на площади Султанахмет перед огромной массой людей, призвав их встать на защиту родины и отстоять ее независимость. В 1920 г. британские оккупационные власти в Стамбуле, распустив парламент, приговорили нескольких сторонников сопротивления к смерти. В их числе была и Х. Эдип. Она вынуждена была уехать в Анкару и присоединиться к Мустафе Кемалю, возглавившему национально-освободительное движение. Она работала в качестве переводчика и пресс-атташе. Свое участие в военных действиях она описала в романе «Дочь Смирны» (1922 г.), посвященному победе турецких войск над греческими в битве у р. Сакарья в 1921 г., и во второй части своих мемуаров под названием «Испытание Турка» («The Turkish Ordeal»), опубликованной в 1928 г. в Нью-Йорке.

В дальнейшем X. Эдип и Мустафра Кемаль Ататюрк разошлись. Она рассчитывала на большее вовлечение женщин в общественную жизнь, на проведение политики в рамках идей демократии и либерализма, была против реформы языка, против реформы одежды, против гонения на ислам и навязывания псевдонаучной версии истории турок. М. Кемаль после прихода к власти установил авторитарное правление и инициировал радикальные преобразования, с чем были не согласны многие его сподвижники 
Савин Д. А.

(К. Карабекир, Рауф Орбай, Х. Эдип, А. Адывар и др.), образовав в 1924 г. оппозиционную Прогрессивную Республиканскую партию. Критика режима со стороны героев войны за независимость и бывших сподвижников К. Ататюрка (1918-1923 гг.) привела к тому, что против них начались гонения и многие вынуждены были мигрировать за границу, особенно после роспуска Прогрессивной Республиканской партии в 1925 г.

$\mathrm{B}$ добровольное изгнание отправилась и семья Х. Эдип. Одной из причин отъезда послужило то, что ее обвинили в желании установить американский мандат в Турции. Писательница, как и многие другие турецкие интеллектуалы, действительно была сторонницей выполнения «14 пунктов Вудро Вильсона», так как считала, что в условиях угрозы, нависшей над страной со стороны европейских держав, США как нейтральная сторона смогла бы оказать помощь Турции в борьбе за независимость. В дальнейшем она изменила свое отношение к проблеме. Для опровержения обвинений в свой адрес Х. Эдип выпустила вторую часть своих мемуаров, посвященную целиком эпохе национально-освободительной борьбы, где подробно раскрывала свою политическую позицию.

Мемуары она писала на английском языке. Они до сих пор по политическим мотивам полностью не опубликованы и не переведены на турецкий язык. Цензура постаралась изъять из текста места с критикой Кемаля Ататюрка. В добровольном изгнании в Великобритании и Франции Х. Эдип продолжала с регулярностью печатать романы, публиковать статьи в прессе, заниматься преподавательской деятельностью, в рамках которой она выступала с лекциями в США и Индии как приглашенный профессор. По итогам поездки в Индию для чтения лекций в Национальном Исламском университете (Jamia Millia Islamia) в 1935 г. в Лахоре была издана ее книга под названием «Противостояние Востока и Запада в Турции». Всего ею было прочитано восемь лекций, посвященных османскому и республиканскому периодам истории Турции, литературе и культуре, турецким женщинам, революции, войне за независимость и будущему Турции. Лекции X. Эдип посетили известные лидеры индийского движения за независимость: С. Найду, Ч. Раджагопалачария и А. А. Али.

В 1937 г. вышла ее книга «Индия изнутри» («Inside India»), в которой она описала свои наблюдения за время пребывания в стране, отдельные аспекты индийского национализма, отношение мусульман к движению за независимость, встречи с М. К. Ганди, Дж. Неру, Абдул-Джафар Ханом, М. Ансари и другими лидерами движения за освобождение. Автор осознала, как в Индии происходило взаимодействие между современностью и традицией, как в плюралистичном обществе сосуществовали различные религии. Она ставила вопрос: совместим ли ислам с современностью [4, p. 187-193] - и отвечала на него положительно. В отличие от К. Ататюрка она рассматривала ислам не как тормоз общественного развития страны, а как важный атрибут культуры, считала, что он не является препятстви- 
ем для прогресса, что прогресса можно достичь только через развитие собственной культуры, перенимая опыт из-за рубежа.

Вернуться в Турцию Х. Эдип смогла только после смерти Кемаля Ататюрка в 1938 г. В 1940 г. она возглавила кафедру английской фрилологии в Стамбульском университете. Ее первая лекция была посвящена творчеству У. Шекспира. В 1950-1954 гг. Х. Эдип стала депутатом Великого национального собрания Турции. Однако она разочаровалась в деятельности пришедшей к власти Демократической партии и, выйдя из парламента, целиком сосредоточилась на научной деятельности в Стамбульском университете, которому отдала последние годы жизни.

Скончалась она 9 января 1964 г. Ее похороны прошли в мечети Баязет рядом с площадью Султанахмет, где она прославилась как оратор. Таким образом, Х. Эдип своим творчеством и политической позицией внесла неоценимый вклад как в литературу Турции, так и общественную жизнь. Ее по праву называли «идеальной моделью» для турецких женщин, так как была хорошо образованной, одевалась на западный манер, но была патриоткой своей страны. Ее труды до сих пор переиздаются, читаются и экранизируются, входят в образовательную программу школ и вузов Турции.

В 2008 г. в Турции вышел в прокат документальный 28-минутный фильм «The Greedy Heart of Halide Edib», рассчитанный на школьников и посвященный жизни и деятельности Халиде Эдип. А 27 октября 2016 г. был запущен сериал «Моя родина - это ты» (Vatanim Sensin) о национально-освободительном движении в Турции, в котором роль Халиде сыграла актриса и модель Сельма Эргеч. В 2014 г. в связи с 50-летием со дня смерти писательницы были выпущены серебряные монеты в количестве 2000 штук и номиналом в 50 лир с ее изображением.

Увековечение ее памяти - свидетельство тому, что в последние годы отношение к X. Эдип в Турции заметно изменилось в лучшую сторону: с подачи К. Ататюрка о ней долгое время писали в прессе как о предателе национальных интересов страны. В настоящее время ее заслуги перед страной признаются, она считается символом турецкой нации наравне с К. Ататюрком.

\section{Ссылки}

1. Сибгатуллина А. Т. Непреклонная Халиде: жизнь и творчество турецкой писательницы Халиде Эдип Адывар. М.: Пробел-2000, 2018. 184 с.

2. Encyclopedia of Woman Social Reformers. Santa-Barbara: ABC, Clio, 2001. Vol. 1.

3. Memoirs of Halide Edip. N.-Y.; L.: The Century Co, 1926. 472 p.

4. Nas A. Inside India, Outside of Kemalism: analysis of Halide Edib`s writtings on anicolonialism // International journal of humanities and social science. 2013, April. Vol. 3, № 7. P. 187-193. 